\title{
Cooperative Catalysis of a Trinuclear Ruthenium(II) Complex in Transfer Hydrogenation of Ketones by Formic Acid
}

Yuichi Yano, ${ }^{1}$ Takahiko Kojima, ${ }^{2, *}$ and Shunichi Fukuzumi ${ }^{1,3, *}$

${ }^{1}$ Department of Material and Life Science, Graduate School of Engineering, Osaka University, Suita, Osaka 565-0871, Japan

${ }^{2}$ Department of Chemistry, University of Tsukuba, 1-1-1 Tennoudai, Tsukuba, Ibaraki 305-8571, Japan

${ }^{3}$ Department of Bioinspired Science, Ewha Womans University, Seoul 120-750, Korea

E-mail:fukuzumi@chem.eng.osaka-u.ac.jp, kojima@chem.tsukuba.ac.jp

* To whom the correspondence should be addressed. 
Abstract - A novel TPA derivative (TPA = tris(2-pyridylmethyl)amine) having two 1,10-phenanthroline (phen) moieties via amide linkage was synthesized and this ligand reacted with $\left[\mathrm{Ru}(\mathrm{hmb}) \mathrm{Cl}_{2}\right]_{2}$ (hmb: hexamethylbenzene) to give a trinuclear $\mathrm{Ru}(\mathrm{II})$ complex, $\left[\mathrm{RuCl}\left(\mathrm{TPA}-\{\text { phenRuCl}(\mathrm{hmb})\}_{2}-\mathrm{H}^{+}\right)\right]\left(\mathrm{PF}_{6}\right)_{2}(\mathbf{1 - C l})$, in a moderate yield. The complex involves a deprotonated and oxygen-coordinated amide linkage, which exhibits reversible protonation-deprotonation equilibrium. The chlorido complex was converted to be an aqua complex, $\left[\mathrm{Ru}\left(\mathrm{H}_{2} \mathrm{O}\right)\left(\mathrm{TPA}-\left\{\text { phenRu}\left(\mathrm{H}_{2} \mathrm{O}\right)_{2}(\mathrm{hmb})\right\}_{2}-\mathrm{H}^{+}\right)\right]\left(\mathrm{SO}_{4}\right)_{5 / 2}$ (1- $\left.\mathbf{H}_{2} \mathrm{O}\right)$, by the reaction of 1-Cl with $\mathrm{Ag}_{2} \mathrm{SO}_{4}$ in $\mathrm{H}_{2} \mathrm{O}$. Transfer hydrogenation of ketones was examined by using 1-Cl as a catalyst and $\mathrm{HCOONa}$ as a hydride source in $\mathrm{H}_{2} \mathrm{O} / \mathrm{CH}_{3} \mathrm{OH}(1: 1 \mathrm{v} / \mathrm{v})$ at $50{ }^{\circ} \mathrm{C}$ under Ar. The time-course of the transfer hydrogenation of cyclohexanone to give cyclohexanol revealed that $\mathbf{1 - C l}$ showed a cooperative effect on the catalytic reactivity as compared with that of mononuclear $[\mathrm{RuCl}(\mathrm{hmb})(\mathrm{phen})]$ (3-Cl) and $\left[\mathrm{RuCl}\left((1-\mathrm{Naph})_{2}-\mathrm{TPA}\right)\right] \mathrm{PF}_{6}$ in $\mathrm{H}_{2} \mathrm{O} / \mathrm{CH}_{3} \mathrm{OH}(1: 2 \mathrm{v} / \mathrm{v})$ under the same conditions. The detailed kinetic study has revealed that the catalytic transfer hydrogenation proceeds via the formato complex, which interacts with a substrate rather than via the hydrido complex. The two Ru centers placed at close proximity in $1-\mathrm{H}_{2} \mathrm{O}$ enhanced the interaction of the formato complex with a substrate, resulting in an increase in the catalytic reactivity as compared with the mononuclear complex. 


\section{Introduction}

Transfer hydrogenation of carbonyl compounds has been one of useful strategies to obtain alcohols which are versatile synthetic precursors to give further functionalized compounds [1,2]. As a hydrogen source in transfer hydrogenation, alcohols such as 2-propanol have been generally utilized [3,4], however, formic acid and formate salts have also been used as shown in Scheme 1 [5]. Since formic acid is a natural product which is produced by ants, the usage of formic acid and formate salts can provide a environmentally benign catalytic hydrogenation process [6], hydrogen production [7], and four-electron reduction of $\mathrm{O}_{2}$ [8]. As catalysts for the transfer hydrogenation, $\mathrm{Rh}(\mathrm{I})$ [9], $\mathrm{Ru}(\mathrm{II})$ [10], and $\mathrm{Ir}(\mathrm{III})$ complexes [11] have been used and proved to be effective catalysts. As ligands of the catalysts for transfer hydrogenation, arenes such as p-cymene [12] and hexamethylbenzene [13] for ruthenium(II) complexes have been the most popular ligands. In the course of the reaction, a hydride complex has been recognized as a key intermediate generated from the reaction of $\mathrm{HCOO}^{-}$with a metal complex concomitant with $\mathrm{CO}_{2}$ release [14].

In catalytic transfer hydrogenation, Noyori and Ikariya and their coworkers have developed mononuclear $\mathrm{Ru}(\mathrm{II})$-arene complexes having $N$-sulfonylated 1,2-diamines as ancillary ligands [15]. In their systems, the amine $\mathrm{N}-\mathrm{H}$ acts as an acid to enhance the reactivity of substrates in cooperation with the $\mathrm{Ru}(\mathrm{II})$ center. This suggests that convergence of reaction centers and cooperative moieties in vicinity would provide higher reactivity than catalysts without aiding groups.

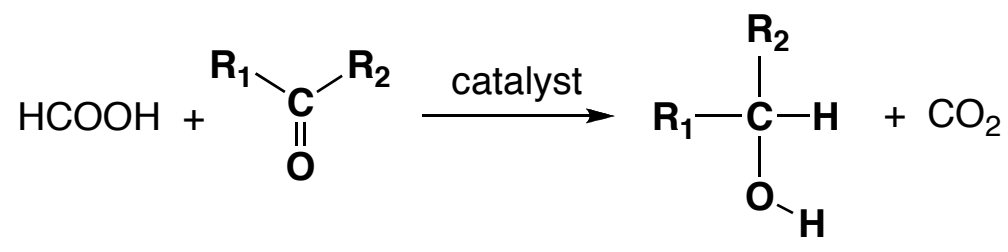

\section{Scheme 1.}


In order to enhance the reactivity of transition metal catalysts, convergence of metal centers in the vicinity can be an important strategy to make them cooperative. This synergy effects have been exemplified in the catalytic activity of transition metal clusters capable of catalyzing sophisticated reactions [16]. Thus far, dinuclear transition metal catalysts for transfer hydrogenation have been investigated [17], however, no example has been reported on dinuclear catalysts bearing converged reaction centers to gain enhanced reactivity. In addition, no mechanistic insights have been given to transfer hydrogenation by those dinuclear catalysts.

We report herein the synthesis and characterization of novel Ru(II)-TPA complexes $(\mathrm{TPA}=\operatorname{tris}(2-$ pyridylmethyl)amine $)$ having $[\mathrm{Ru}(\mathrm{X})($ arene $)(1,10-$ phenanthroline $)](\mathrm{X}=$ $\mathrm{Cl}, \mathrm{H}_{2} \mathrm{O}$; arene $=p$-cymene, $\left.\mathrm{C}_{6}\left(\mathrm{CH}_{3}\right)_{6}\right)$ moieties connected by amide linkages as a converged reaction center. Its application to the catalytic transfer hydrogenation of ketones with use of HCOONa as a hydrogen source was examined in aqueous media. The kinetic analysis on the transfer hydrogenation provides valuable insight into the catalytic mechanism. In this case, the Ru(II) ion coordinated to the TPA moiety acts as a template to converge the two amide-linked phen pendant arms as metal binding sites [18]. This strategy allows us to put two reaction centers in the close vicinity, enabling them to function in a cooperative manner.

\section{Results and Discussion}

\section{Preparation of Ru-trinuclear Complexes}

A novel TPA derivative having two 1,10-phenanthroline (phen) pendants via amide linkage was synthesized by coupling reaction between bis(6-amino-2pyridylmethyl)-(2-pyridylmethyl)amine (diamino-TPA) [19] and 4-chlorocarbonyl-phen [20] in tetrahydrofurane (THF) in the presence of triethylamine as a base and 4- $(N$, $\mathrm{N}$-dimethylamino)pyridine (DMAP) as a catalyst. The ligand (TPA-phen ${ }_{2}$ ) was purified 
by column chromatography on an activated alumina with $\mathrm{CHCl}_{3}$ as an eluent including $1 \%$ of $\mathrm{NH}_{3}$ aqueous solution and isolated in $67 \%$ yield.
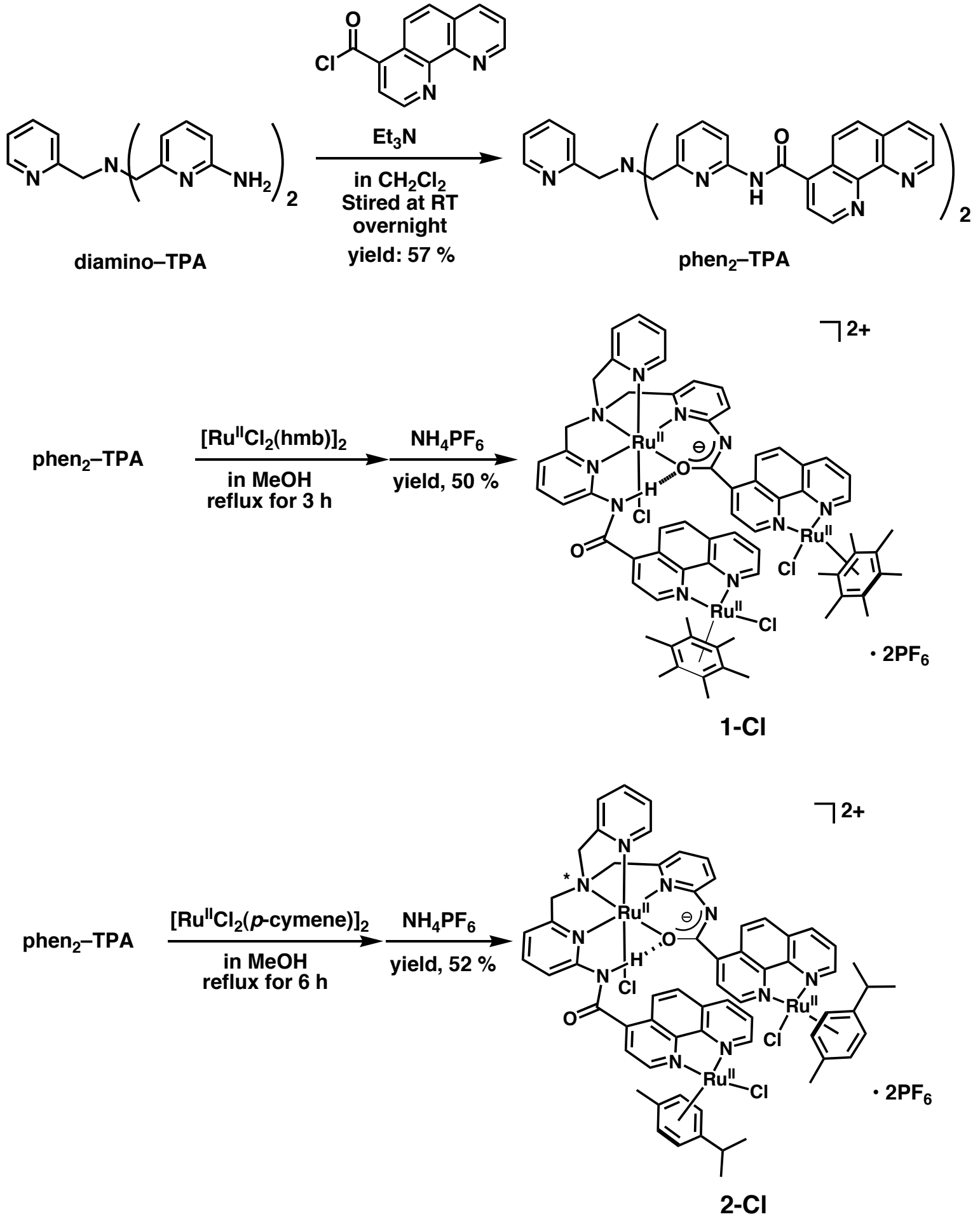

Scheme 2. Synthetic routes of (phen) ${ }_{2}-\mathrm{TPA}, \mathbf{1 - C l}$, and 2-Cl. 
The ligand reacted with dimeric precursor complexes, $\left[\mathrm{RuCl}_{2}(\text { arene })\right]_{2}$ (arene $=$ hexamethylbenzene (hmb) and p-cymene (cym)), to give trinuclear $\mathrm{Ru}(\mathrm{II})$ complexes, $\left[\mathrm{RuCl}\left\{\mathrm{TPA}-(\text { phenRuCl}(\mathrm{hmb}))_{2}-\mathrm{H}^{+}\right\}\right]\left(\mathrm{PF}_{6}\right)_{2} \quad(\mathbf{1 - C l}) \quad$ and $\quad \mathrm{RuCl}\{\mathrm{TPA}-($ phenRuCl$($ cym $\left.\left.))_{2}-\mathrm{H}^{+}\right\}\right]\left(\mathrm{PF}_{6}\right)_{2}(\mathbf{2}-\mathbf{C l})$ in 50 and $52 \%$ yields, respectively. ${ }^{1} \mathrm{H}$ NMR spectra of both complexes in $\mathrm{CD}_{3} \mathrm{CN}$ exhibited three $\mathrm{AB}$ quartets assigned to the methylene protons in the ligand, indicating an asymmetric coordination environment due to the coordination of one of amide oxygen atoms as observed in related $\mathrm{Ru}(\mathrm{II})$ complexes reported so far $[18,19,21,22]$. On the base of charge balance, the coordinated amide linkage should be deprotonated to make TPA-phen 2 act as a monoanionic pentadentate ligand. This deprotonation may be derived from an electron-withdrawing effect of the cationic $\left[\mathrm{RuCl}(\text { arene)(phen) }]^{+}\right.$moiety to enhance the acidity of the $\mathrm{N}-\mathrm{H}$ proton in the coordinated amide linkage. ESI-MS spectra of 1-Cl and 2-Cl showed peak clusters ascribed to $\left\{\mathbf{1 - C l}-\left(\mathrm{PF}_{6}\right)_{2}\right\}^{2+}(\mathrm{m} / \mathrm{z}=733.0)$ and $\left\{\mathbf{2}-\mathbf{C l}-\left(\mathrm{PF}_{6}\right)_{2}\right\}^{2+}(\mathrm{m} / \mathrm{z}=705.3)$, supporting the formation of the trinuclear complexes.

In order to make 1-Cl more soluble into aqueous media and to make it more

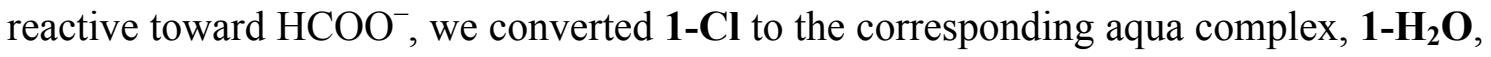
by the reaction of 1-Cl with $\mathrm{Ag}_{2} \mathrm{SO}_{4}$ in $\mathrm{H}_{2} \mathrm{O}$. This complex was also characterized by absorption and ${ }^{1} \mathrm{H}$ NMR spectroscopies and ESI-MS spectrometry. In the absorption spectrum of $\mathbf{1 - H _ { 2 }} \mathbf{O}$, an absorption band at $432 \mathrm{~nm}$ for the chloro complex 1-Cl disappeared and a shoulder peak was just observed at $416 \mathrm{~nm}$. Its ${ }^{1} \mathrm{H}$ NMR spectrum was broadened compared to the corresponding chloro complex probably due to slow exchange of the aqua ligands. The three $\mathrm{AB}$ quartets shifted to slightly upper field in comparison with those of 1-Cl. The complex exhibited a peak cluster at $m / z=727.6$ $\left(\left[\mathrm{M}-3 / 2\left(\mathrm{SO}_{4}\right)-3 \mathrm{H}_{2} \mathrm{O}\right]^{2+}\right)$.

\section{Transfer Hydrogenation Reactions}

We examined transfer hydrogenation of cyclohexanone $(100 \mathrm{mM})$ to produce 
cyclohexanol using 1-Cl and 2-Cl $(0.5 \mathrm{mM})$ as catalysts with $\mathrm{HCOONa}(500 \mathrm{mM})$ as a hydrogen source at $50{ }^{\circ} \mathrm{C}$ in aqueous media, $\mathrm{D}_{2} \mathrm{O} / \mathrm{CD}_{3} \mathrm{OD}(1: 1 \mathrm{v} / \mathrm{v}$ for $\mathbf{1 - C l}$ and $7: 3 \mathrm{v} / \mathrm{v}$ for 2-Cl). By means of ${ }^{1} \mathrm{H}$ NMR measurements on the reaction mixtures, catalytic turnover numbers (TON) were obtained to be 46 for 1-Cl (44 h) and 21 for 2-Cl (43 h), respectively. A blank experiment was performed to demonstrate that the transfer hydrogenations do not occur in the absence of catalyst. The turnover numbers were determined on the basis of the ratio of peak integration values of a multiplet signal due to cyclohexanone at $2.38 \mathrm{ppm}$ between that at the beginning and that at an appropriate reaction time, since cyclohexanol giving a multiplet at 1.24 ppm was the sole product. Mononuclear complexes, $\quad[\mathrm{RuCl}(\mathrm{phen})(\mathrm{hmb})] \mathrm{PF}_{6} \quad(\mathbf{3}-\mathbf{C l}) \quad[23,24] \quad$ and $[\mathrm{RuCl}(\mathrm{phen})(\mathrm{cym})] \mathrm{PF}_{6}$ [23.24], exhibited TONs of 13 and 4, respectively, under the conditions mentioned above. Thus, we concluded that the hmb derivative should be more reactive than the cym counterpart. We will discuss on the hmb complexes including 1-Cl hereafter.

Time-course of turnover numbers are shown in Fig. 1 for catalytic transfer hydrogenation of cyclohexanone $(100 \mathrm{mM})$ by $\mathbf{1 - C l}$ and 3-Cl $(0.5 \mathrm{mM})$ with HCOONa $(500 \mathrm{mM})$ in $\mathrm{D}_{2} \mathrm{O} / \mathrm{CD}_{3} \mathrm{OD}(1: 1 \mathrm{v} / \mathrm{v})$ at $50{ }^{\circ} \mathrm{C}$. Since the Ru-TPA moiety was revealed to show only a low reactivity using $\left[\mathrm{RuCl}(1 \text {-naphthoylamide })_{2}-\mathrm{TPA} \mathrm{PF}_{6}\right.$ under the same conditions, it is concluded that the catalytic reaction proceeds by the two pendant $\mathrm{Ru}(\mathrm{hmb})$ (phen) moieties. As can be seen in the figure, the turnover numbers of 1-Cl is nearly 3-fold larger than those of the mononuclear complex 3-Cl. Thus, a cooperative effect is operating between the two $\mathrm{Ru}(\mathrm{hmb})(\mathrm{phen})$ moieties in 1-Cl for the catalytic hydrogenation of cyclohexanone. 


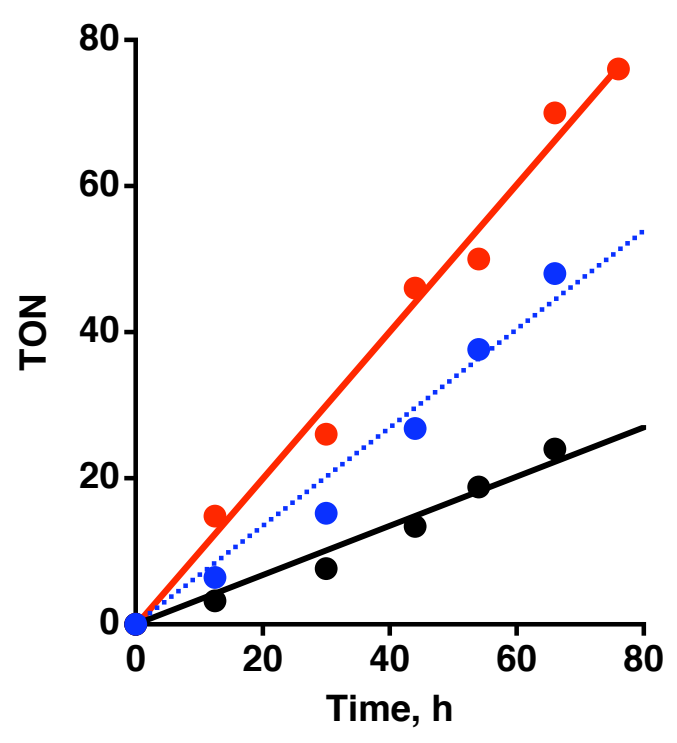

Fig. 1. Time-course of catalytic turnover numbers in transfer hydrogenation of cyclohexanone in $\mathrm{D}_{2} \mathrm{O} / \mathrm{CD}_{3} \mathrm{OD}(1: 1 \mathrm{v} / \mathrm{v})$ at $50{ }^{\circ} \mathrm{C}$ under Ar. Red line, 1-Cl; black line, 3; blue dotted line, doubled values on the black line.

We also examined other ketones as substrates for transfer hydrogenation using 1-Cl and 3-Cl in $\mathrm{D}_{2} \mathrm{O} / \mathrm{CD}_{3} \mathrm{OD}(1: 1 \mathrm{v} / \mathrm{v})$ at $50{ }^{\circ} \mathrm{C}$ under Ar. The results are summarized in

\section{Table 1}

Turnover numbers for transfer hydrogenation of ketones as substrates by $\mathbf{1 - C l}$ and $\mathbf{3 - C l}$ as catalysts at $50{ }^{\circ} \mathrm{C}$ under $\mathrm{Ar} .{ }^{\text {a }}$

\begin{tabular}{|c|c|c|c|c|c|}
\hline cat. & substrate & product & TON & $t(h)$ & conv. (\%) \\
\hline $\begin{array}{l}1-\mathrm{Cl} \\
3-\mathrm{Cl}\end{array}$ & & & $\begin{array}{r}100 \\
39\end{array}$ & $\begin{array}{l}80 \\
80\end{array}$ & $\begin{array}{l}50 \\
19\end{array}$ \\
\hline $\begin{array}{l}1-\mathrm{Cl} \\
3-\mathrm{Cl}\end{array}$ & & & $\begin{array}{r}100 \\
42\end{array}$ & $\begin{array}{l}20 \\
20\end{array}$ & $\begin{array}{l}50 \\
21\end{array}$ \\
\hline $\begin{array}{l}1-\mathrm{Cl} \\
3-\mathrm{Cl}\end{array}$ & & & $\begin{array}{r}100 \\
34\end{array}$ & $\begin{array}{l}148 \\
148\end{array}$ & $\begin{array}{l}50 \\
17\end{array}$ \\
\hline $\begin{array}{l}1-\mathrm{Cl} \\
3-\mathrm{Cl}\end{array}$ & & & $\begin{array}{r}100 \\
36\end{array}$ & $\begin{array}{l}256 \\
256\end{array}$ & $\begin{array}{l}50 \\
18\end{array}$ \\
\hline
\end{tabular}


Table 1. Benzaldehyde, acetophenone, and benzophenone also underwent transfer hydrogenation to give benzyl alcohol, 1-phenylethanol, and diphenylmethanol as the sole products, respectively. Among those, benzaldehyde was the most active substrate among ketones examined as substrates. In order to obtain 100 turnovers by using 1-Cl, it took $20 \mathrm{~h}$ for benzaldehyde, $80 \mathrm{~h}$ for cyclohexanone, $148 \mathrm{~h}$ for acetophenone, and 256 $\mathrm{h}$ for benzophenone. In the same period of time, 3-Cl gave 42, 39, 34, and 36 as turnover numbers for corresponding substrates. The ratios of turnover numbers between that of $\mathbf{1 - C l}$ and that of $\mathbf{3 - C l}$ were in the range of $2.4-3.0$, indicating all the substrates were hydrogenated at significantly higher rates by $\mathbf{1 - C l}$ with converged reaction centers. Thus, it is concluded that all the examined substrates undergo transfer hydrogenation efficiently by a cooperative effect of the two reaction centers.

\section{Mechanistic Insights into Transfer Hydrogenation}

The ESI-MS measurements were performed to detect the reaction intermediates for the catalytic hydrogenation with $\mathbf{1}-\mathbf{H}_{\mathbf{2}} \mathbf{O}$ and $\mathbf{3}-\mathbf{H}_{\mathbf{2}} \mathbf{O}$. The formato complex $(\mathrm{m} / \mathrm{z}=489.2)$ was observed at $10 \mathrm{~s}$ after mixing the mononuclear complex $3-\mathrm{H}_{2} \mathrm{O}[24](0.1 \mathrm{mM})$ and HCOONa $(10 \mathrm{mM})$ in $\mathrm{H}_{2} \mathrm{O}$ at $50{ }^{\circ} \mathrm{C}$ as shown in Fig. 2a (black line) and Fig. 2c. At 30 min the aqua complex was converted to the hydride complex of $3-\mathrm{H}_{2} \mathrm{O}(\mathrm{m} / \mathrm{z}=445.2)$ in

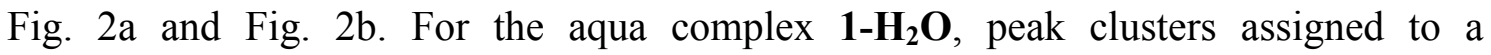
monoformato and a monohydrido complex $\left(\left\{\mathbf{1}-\mathbf{H}_{2} \mathbf{O}-3 \mathrm{H}_{2} \mathrm{O}+\mathrm{HCOO}^{-}-\mathrm{H}^{+}+\mathrm{H}^{-}\right\}^{2+}=\right.$ 703.0) were observed at $30 \mathrm{~min}$ after mixing 1- $\mathrm{H}_{2} \mathrm{O}$ and $\mathrm{HCOONa}$ (Fig. 3). It should be noted that no peaks assignable to a diformato complex were observed.

The kinetics for the formation of the hydrido complexes derived from $1-\mathrm{H}_{2} \mathrm{O}$ and 3- $\mathrm{H}_{2} \mathrm{O}$ was examined by following absorption spectral change in the course of the reactions of $1-\mathrm{H}_{2} \mathrm{O}$ and $3-\mathrm{H}_{2} \mathrm{O}$ with $\mathrm{HCOO}^{-}$. The hydrido complex derived from $1-\mathrm{H}_{2} \mathrm{O}$ exhibited the absorption maximum at $500 \mathrm{~nm}$ (Fig. 4a) and the time profile of an increase in absorbance at $500 \mathrm{~nm}$ obeyed the pseudo-first-order kinetics (Fig. 4b). 

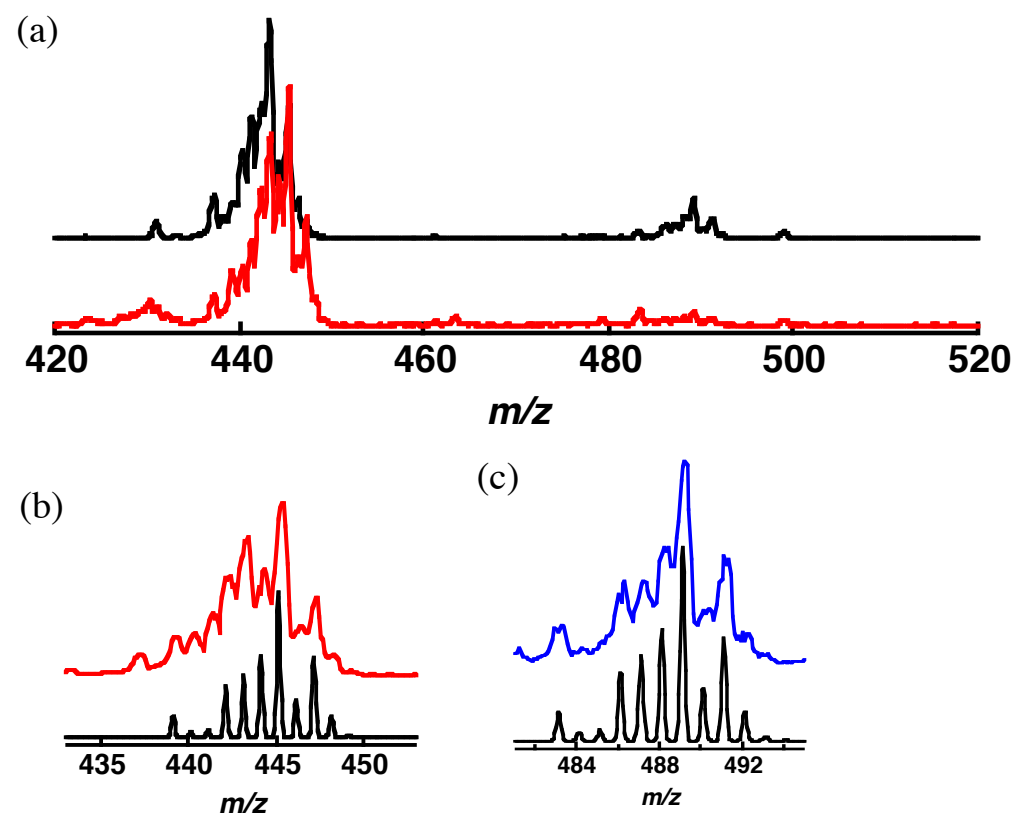

Fig. 2. (a) ESI-MS spectra observed in the reaction of $3-\mathrm{H}_{2} \mathrm{O}$ with $\mathrm{HCOONa}(10 \mathrm{mM})$ in water at $323 \mathrm{~K}$ (black: $10 \mathrm{~s}$, red: $30 \mathrm{~min}$ ). (b) ESI-MS spectrum of the monohydrido complex of $3-\mathrm{H}_{2} \mathrm{O}$ and its isotope simulation spectrum. (c) ESI-MS spectrum of the formate complex of $3-\mathrm{H}_{2} \mathrm{O}$ and its isotope simulation spectrum.

(a)

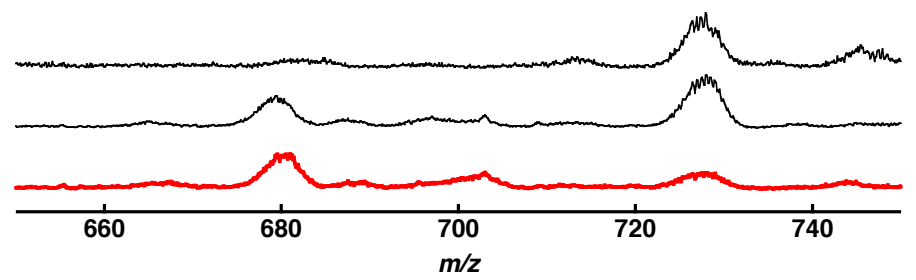

(b)

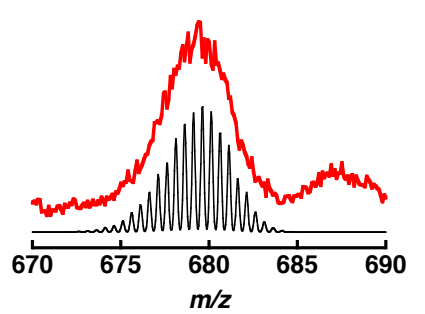

(c)

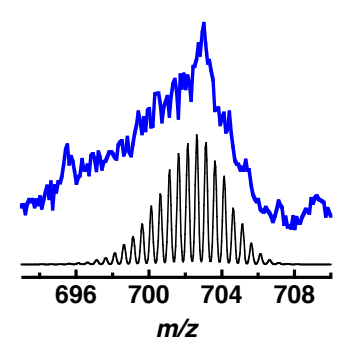

Fig. 3. (a) ESI-MS spectra observed in the reaction of $1-\mathrm{H}_{2} \mathrm{O}$ with $\mathrm{HCOONa}(10 \mathrm{mM})$ in water at $323 \mathrm{~K}$ (black: $10 \mathrm{~s}$, red: $30 \mathrm{~min}$ ). (b) ESI-MS spectrum of the monohydrido complex of 1- $\mathrm{H}_{2} \mathrm{O}$ and its isotope simulation spectrum. (c) ESI-MS spectrum of the formate complex of $\mathbf{1}-\mathrm{H}_{2} \mathrm{O}$ and its isotope simulation spectrum. 


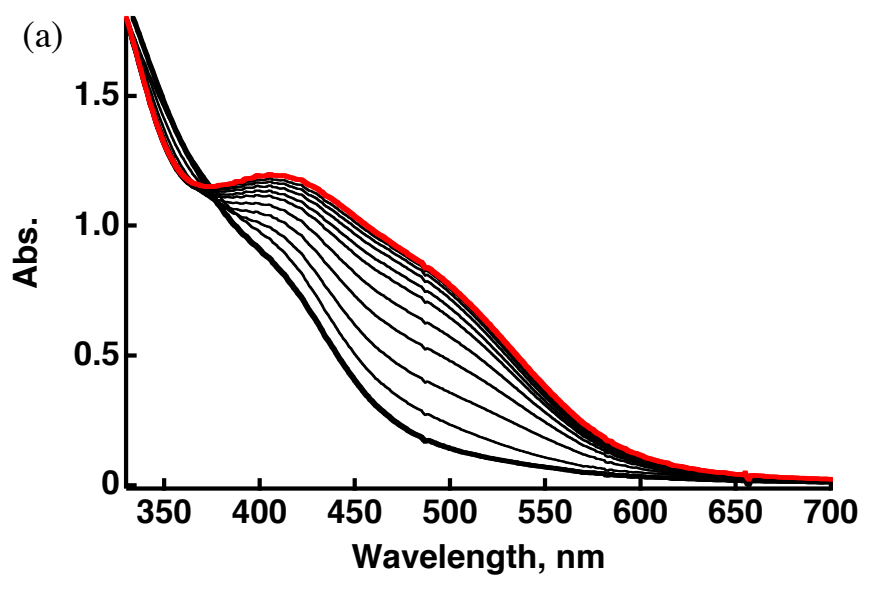

(b)

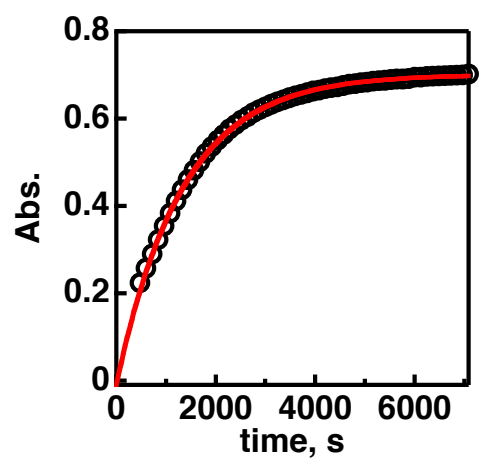

Fig. 4. (a) Absorption spectral change observed in the reaction of $1-\mathrm{H}_{2} \mathrm{O}(0.10 \mathrm{mM})$ with HCOONa $(10 \mathrm{mM})$ in water at $323 \mathrm{~K}$. (b) Time profile of absorbance at $500 \mathrm{~nm}$ due to the hydrido complex derived from $1-\mathrm{H}_{2} \mathrm{O}$.

The observed pseudo-first-order rate constant $\left(k_{\mathrm{obs}}\right)$ exhibits a saturation behavior with increasing concentration of $\mathrm{HCOO}^{-}$(Fig. 5). The formation of the hydrido complex from 3- $\mathrm{H}_{2} \mathrm{O}$ exhibits similar kinetic behavior (Fig. S1). The saturation behavior of $k_{\mathrm{obs}}$ relative to the concentration of $\mathrm{HCOO}^{-}$suggests that the formation of the hydrido complexes proceeds via the formato complexes as shown in Scheme 3.

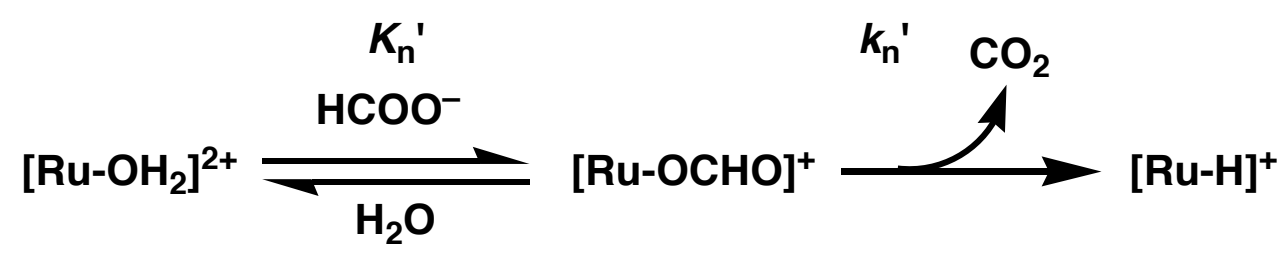

Scheme 3 


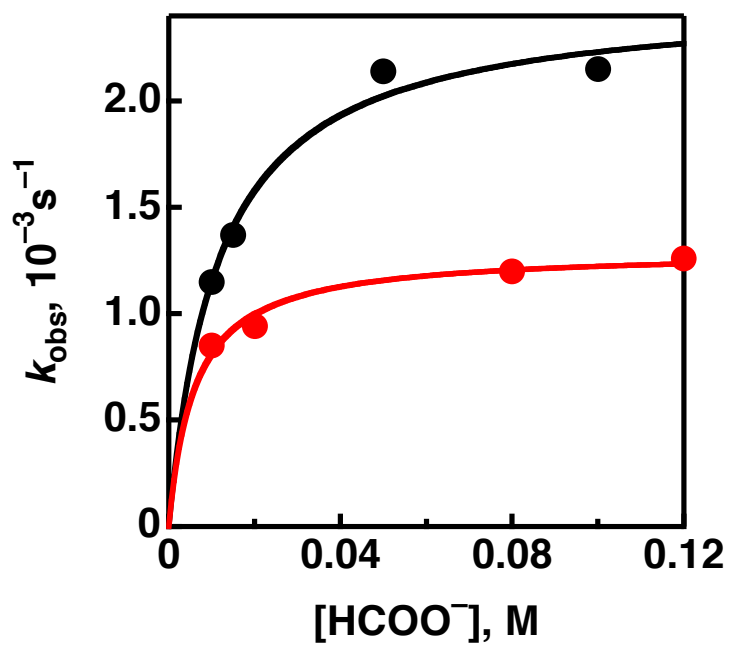

Fig. 5. Plots of $k_{\mathrm{obs}}$ vs. [HCOO$\left.{ }^{-}\right]$for the reaction of $\mathbf{1}-\mathrm{H}_{2} \mathrm{O}(\mathrm{red}, 0.10 \mathrm{mM})$ and $\mathbf{3}-\mathrm{H}_{2} \mathrm{O}$ (black, $0.10 \mathrm{mM})$ with HCOONa $(10 \mathrm{mM})$ in water at $323 \mathrm{~K}$.

According to Scheme 3, the dependence of $k_{\mathrm{obs}}$ on concentration of $\mathrm{HCOO}^{-}$is given by Eq. (1). By fitting the data in Fig. 5, the formation constants of the formato complexes derived from 1- $\mathrm{H}_{2} \mathrm{O}$ and $3-\mathrm{H}_{2} \mathrm{O}\left(K_{1}\right.$ and $K_{2}$, respectively) and the rate constants of the formation of

$$
k_{\mathrm{obs}}=\left(k_{\mathrm{n}} K_{\mathrm{n}}\left[\mathrm{HCOO}^{-}\right]\right) /\left(1+K_{\mathrm{n}}\left[\mathrm{HCOO}^{-}\right]\right) \quad(\mathrm{n}=1,2)
$$

the hydrido complexes of $\mathbf{1}-\mathrm{H}_{2} \mathrm{O}$ and $3-\mathrm{H}_{2} \mathrm{O}\left(k_{1}\right.$ and $k_{2}$, respectively) were determined to be $K_{1}=167 \mathrm{M}^{-1}, K_{2}=87 \mathrm{M}^{-1}, k_{1}=1.3 \times 10^{-3} \mathrm{~s}^{-1}, k_{2}=2.5 \times 10^{-3} \mathrm{~s}^{-1}$.

Next, the rates of reactions of the hydride complexes of $1-\mathrm{H}_{2} \mathrm{O}$ and $3-\mathrm{H}_{2} \mathrm{O}$ with cyclohexanone were determined by monitoring the decay of absorbance at 500 and 450 $\mathrm{nm}$ due to the hydrido complexes derived from $1-\mathrm{H}_{2} \mathrm{O}$ and $3-\mathrm{H}_{2} \mathrm{O}$, respectively. The absorption spectral change in the course of reaction of the hydrido complex derived from 1- $\mathrm{H}_{2} \mathrm{O}$ with cyclohexanone is shown in Fig. 6a. The decay of absorbance at 500 $\mathrm{nm}$ due to the hydrido complex derived from $1-\mathrm{H}_{2} \mathrm{O}$ obeys pseudo-first-order kinetics (Fig. 6b) and the pseudo-first-order rate constant $\left(k_{\text {obs }}\right)$ exhibits a saturation behavior 
(a)

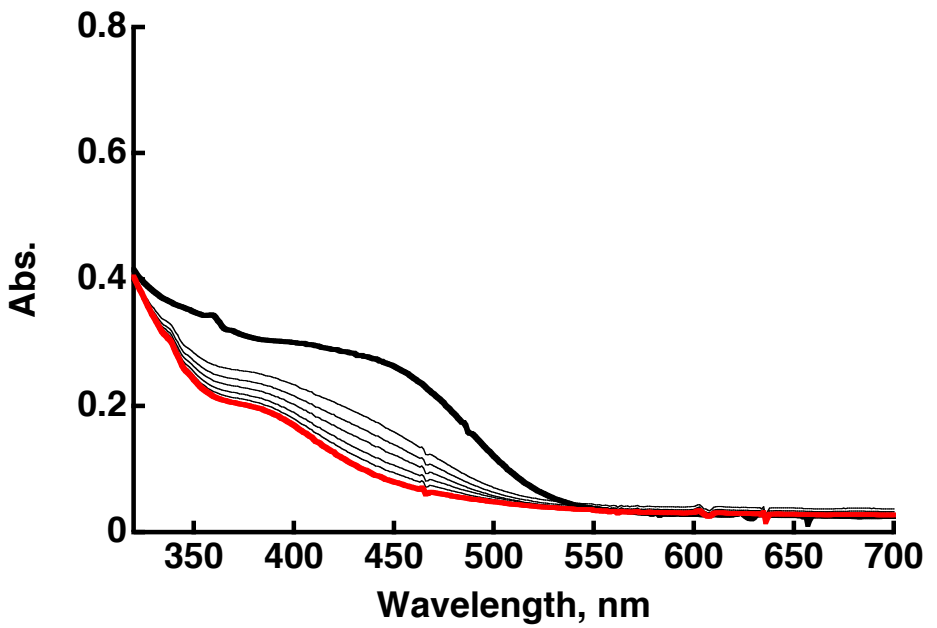

(b)

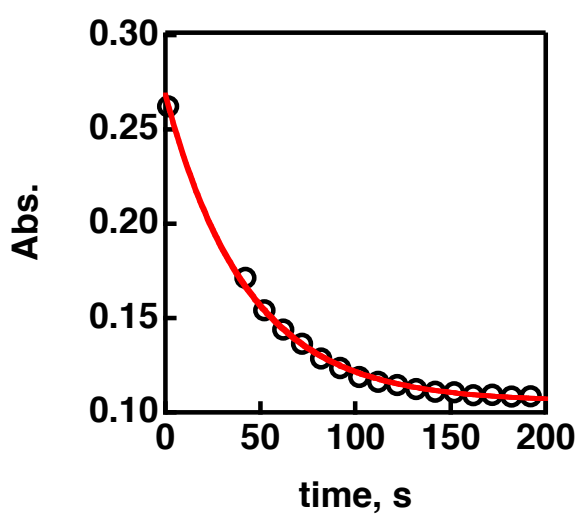

Fig. 6. (a) Absorption spectral change observed in the reaction of the hydride complex derived from $1-\mathrm{H}_{2} \mathrm{O}(0.10 \mathrm{mM})$ with cyclohexanone $(10 \mathrm{mM})$ in water at $323 \mathrm{~K}$. (b) Time profile of absorbance at $450 \mathrm{~nm}$ due to the hydride complex derived from $1-\mathrm{H}_{2} \mathrm{O}$.

with increasing concentration of cyclohexanone as shown in Fig. 7. Such a saturation behavior of $k_{\mathrm{obs}}$ on substrate concentration suggests that the hydride complex forms a complex with cyclohexanone prior to the hydrogenation reaction (Scheme 4) [25].

According to Scheme 4, the dependence of $k_{\mathrm{obs}}$ on substrate concentration [S] is given by Eq. (2), where $K_{1}{ }^{\prime}$ and $k_{1}$ ' are the formation constant of the hydride-substrate

$$
k_{\mathrm{obs}}=k_{\mathrm{n}}{ }^{\prime} K_{\mathrm{n}}{ }^{\prime}[\mathrm{S}] /\left(1+K_{\mathrm{n}}{ }^{\prime}[\mathrm{S}]\right) \quad(\mathrm{n}=1,2)
$$


complex of $1-\mathrm{H}_{2} \mathrm{O}$ and the rate constant of the hydrogenation of cyclohexanone in the complex. By fitting the data in Fig. 7, the formation constants of the hydrido-substrate complexes of $1-\mathrm{H}_{2} \mathrm{O}\left(K_{1}{ }^{\prime}\right)$ and the rate constant of the hydrogenation reaction $\left(k_{1}{ }^{\prime}\right)$ were

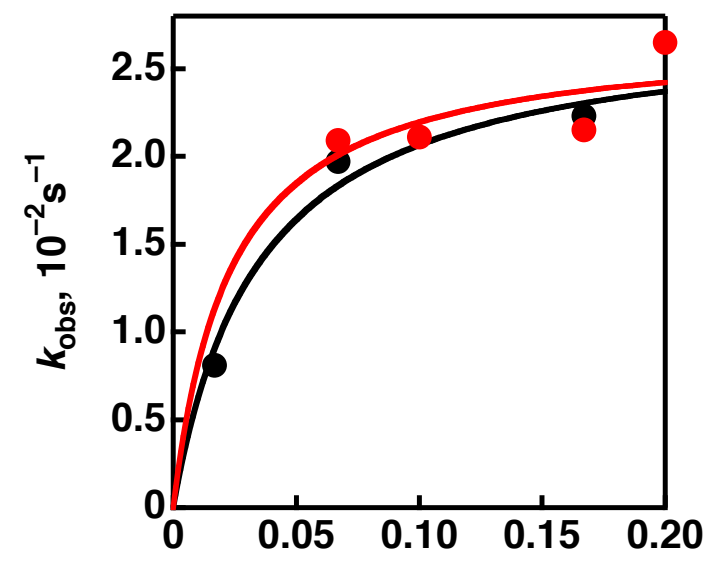

[S], M

Fig. 7. Plots of $k_{\mathrm{obs}}$ vs. concentration of cyclohexanone [S] for the reaction of the hydride complexes of $1-\mathrm{H}_{2} \mathrm{O}$ (red, $0.10 \mathrm{mM}$ ) and $3-\mathrm{H}_{2} \mathrm{O}$ (black, $0.10 \mathrm{mM}$ ) with cyclohexanone in water at $323 \mathrm{~K}$.

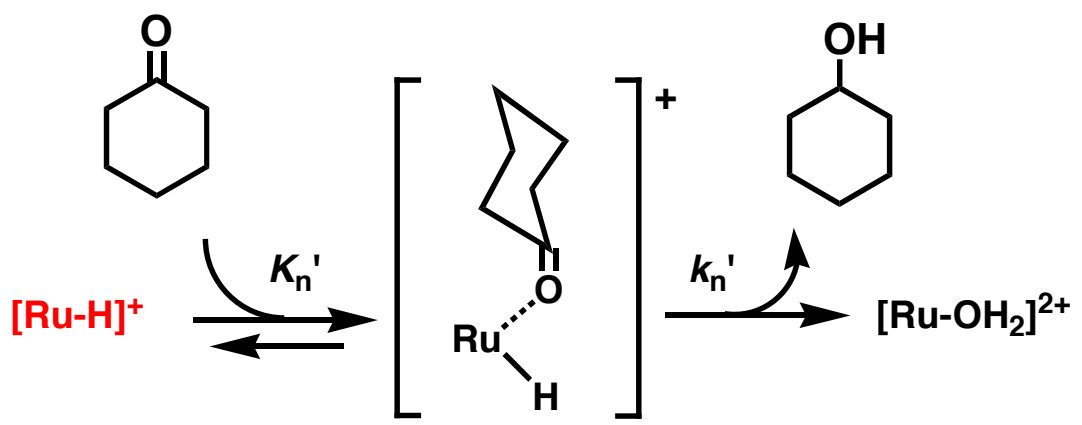

\section{Scheme 4.}

determined to be $43 \mathrm{M}^{-1}, k_{1}=2.7 \times 10^{-2} \mathrm{~s}^{-1}$, respectively. Similarly the $K_{2}{ }^{\prime}$ and $k_{2}{ }^{\prime}$ values of $3-\mathrm{H}_{2} \mathrm{O}$ were determined to be $29 \mathrm{M}^{-1}$ and $2.8 \times 10^{-2} \mathrm{~s}^{-1}$, respectively.

The $k_{1}$ and $k_{2}$ values of formation of the hydrido complexes of $1-\mathrm{H}_{2} \mathrm{O}$ and $3-\mathrm{H}_{2} \mathrm{O}$ are one-order of magnitude larger than the $k_{1}{ }^{\prime}$ and $k_{2}{ }^{\prime}$ values of reactions of the hydrido complexes of $1-\mathrm{H}_{2} \mathrm{O}$ and $3-\mathrm{H}_{2} \mathrm{O}$ with cyclohexanone. In such a case, if the catalytic 
hydrogenation of cyclohexanone with $\mathrm{HCOO}^{-}$proceeds via formation of the hydrido complexes, the TON would be constant irrespective of difference in substrates, because the formation of the hydrido complexes is the rate-determining step. However, the TON is different depending on substrates (Table 1). Such difference in TON suggests that a substrate interacts with the formato complexes prior to formation of the hydrido complexes under the catalytic transfer hydrogenation conditions as shown in Scheme 5. In such a case, the two $\mathrm{Ru}$ centers in the formato complex of $1-\mathrm{H}_{2} \mathrm{O}$ facilitate the interaction with a substrate as compared with that of the mononuclear complex $3-\mathrm{H}_{2} \mathrm{O}$. Thus, the enhancement of the catalytic reactivity of $1-\mathrm{H}_{2} \mathrm{O}$ as compared to the mononuclear complex $3-\mathrm{H}_{2} \mathrm{O}$ may result from the cooperative function of two $\mathrm{Ru}$ centers in the formato complex of $\mathbf{1}-\mathrm{H}_{2} \mathrm{O}$ (Scheme 5).

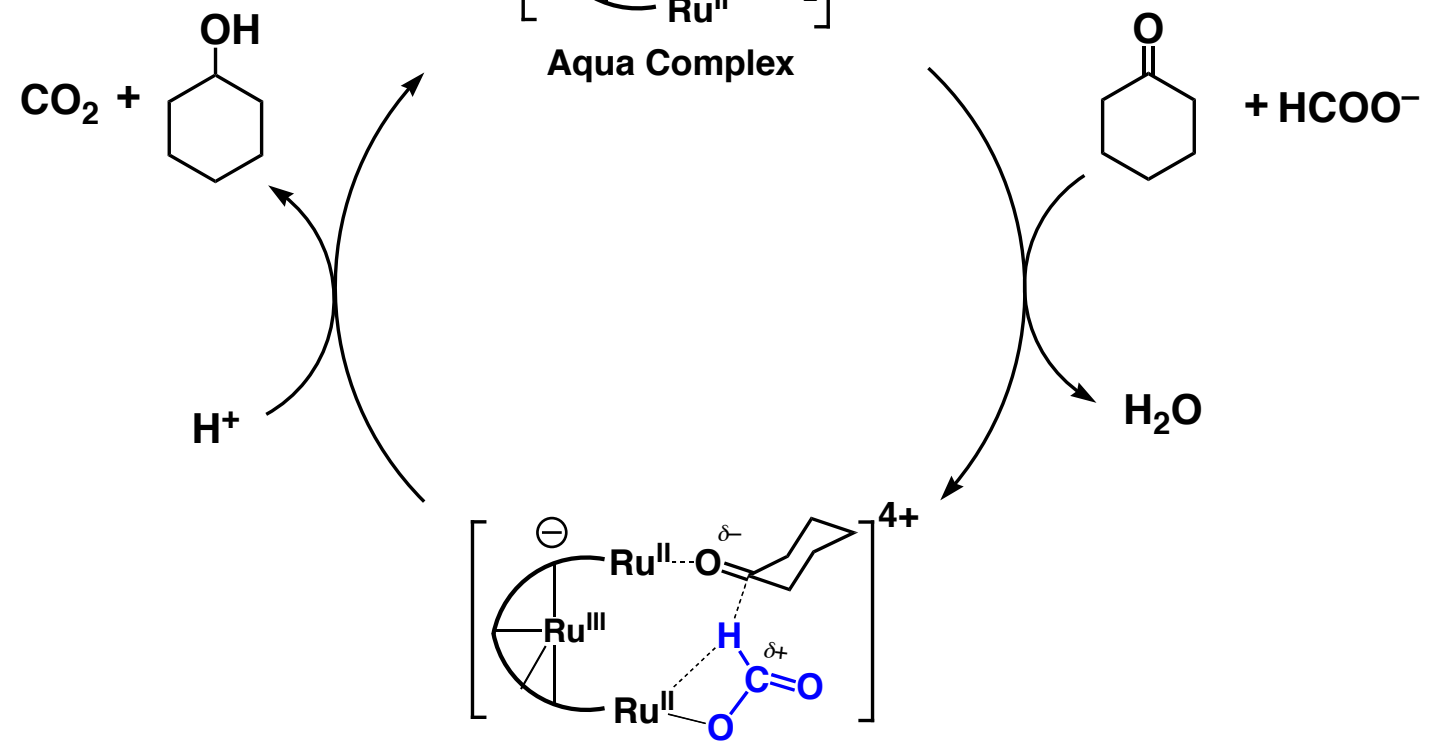

\section{Scheme 5}

\section{Summary and Conclusion}


We have synthesized a novel TPA derivative having two phen moieties via amide linkages at the 6-positions of the two pyridine rings of TPA. The ligand reacts with a dinuclear precursor complexes formulated as $\left[\mathrm{RuCl}_{2}(\text { arene })\right]_{2}$ to give novel trinulcear $\mathrm{Ru}$ (II) complexes. In the $\mathrm{Ru}(\mathrm{II})$-TPA moiety, one of the amide oxygen atoms coordinates to the $\mathrm{Ru}(\mathrm{II})$ center which acts as a template to converge two $[\mathrm{RuCl}(\text { arene })(\text { phen })]^{+}$moieties into a vicinity in its coordination sphere. Enhancement in the catalytic performance was observed for transfer hydrogenation of ketones by $\mathrm{HCOONa}$ as a hydride source with a trinuclear $\mathrm{Ru}(\mathrm{II})$ complex with converged reaction centers in $\mathrm{D}_{2} \mathrm{O} / \mathrm{CD}_{3} \mathrm{OD}$ at $50{ }^{\circ} \mathrm{C}$ as compared to that of the mononuclear counterpart. A monoformato complex derived from the reaction of $1-\mathrm{H}_{2} \mathrm{O}$ with $\mathrm{HCOONa}$ and a hydride complex derived from $\beta$-elimination of the formato intermediate were detected by ESI-MS spectrometry. The kinetic analysis revealed that the two Ru centers in the formato complex of $1-\mathrm{H}_{2} \mathrm{O}$ facilitate the cooperative interaction with a substrate to enhance the catalytic reactivity as compared with that of the mononuclear complex $3-\mathrm{H}_{2} \mathrm{O}$.

\section{Experimental Section}

\section{Materials and Methods}

$\mathrm{CH}_{2} \mathrm{Cl}_{2}$ and triethylamine $\left(\mathrm{Et}_{3} \mathrm{~N}\right)$ were distilled on $\mathrm{CaH}_{2}$ under $\mathrm{N}_{2}$ prior to use. Purification of water was performed with distilled water system. Phenanthroline-COOH (Phen-COOH) [20] and $N, N$-bis(6-amino-2-pyridylmethyl)- $N$-(2-pyridylmethyl)amine [19] were prepared according to literature methods. [ $\left.\mathrm{Ru}^{\mathrm{II}} \mathrm{Cl}(\mathrm{phen})(\mathrm{hmb})\right] \mathrm{PF}_{6}$ and $\left[\mathrm{Ru}^{\mathrm{II}}\left(\mathrm{H}_{2} \mathrm{O}\right)(\right.$ phen $\left.)(\mathrm{hmb})\right] \mathrm{SO}_{4}$ were prepared according to literature methods [23.24] and their purity was checked by elemental analysis [26]. Other chemicals were purchased from appropriate commercial sources and as received without further purification unless mentioned. All NMR measurements were performed on a JEOL AL-300 spectrometer, 
and the chemical shifts were determined by using the residual solvent peak as reference. ESI-MS Spectra were recorded on API-300 triple-quadrupole mass spectrometer (PE-Sciex). UV-vis absorption spectra were recorded on Hewlett-Packard HP8453 photodiode array spectrophotometer at room temperature and at $50{ }^{\circ} \mathrm{C}$ for the kinetics measurements.

Synthesis of N,N-Bis(6-phenanthrolineamide-2-pyridylmethyl)-N-(2-pyridylmethyl)amine((phen $\left.)_{2}-T P A\right)$

In a three-necked flask, phenanthroline-COOH (319 mg, $1.42 \mathrm{mmol})$ was added, dried under vacuum, and then the flask was filled with Ar. Thionylchloride $(20 \mathrm{ml})$ was added as a reactant and the solvent, and the mixture was allowed to reflux for $4.5 \mathrm{~h}$. The color of the solution was changed from colorless to orange, and then the solution was cooled to room temperature. The solvent was removed under vacuum, and the resulting bright orange residue was dissolved in $\mathrm{CH}_{2} \mathrm{Cl}_{2}(10 \mathrm{ml})$. To the solution was added dropwise the solution of $N, N$-bis(6-amino-2-pyridylmethyl)- $N$-(2-pyridylmethyl)amine (227 mg, $0.71 \mathrm{mmol})$ and $\mathrm{Et}_{3} \mathrm{~N}(1 \mathrm{ml})$ in $\mathrm{CH}_{2} \mathrm{Cl}_{2}(15 \mathrm{ml})$. After completion of the addition, the reaction mixture was stirred at room temperature for overnight. The white precipitate of triethylammonium chloride was filtered off and the filtrate was washed with saturated aqueous $\mathrm{NaHCO}_{3}$, followed by water, and then dried over $\mathrm{MgSO}_{4}$. Column chromatography on aluminum oxide eluted with chloroform/1\% $\mathrm{NH}_{3}$ (aq) (95:5) $\left(R_{f}: 0.30\right)$ gave (phen) $)_{2}$ TPA $(258 \mathrm{mg})$ as a white powder in $60 \%$ yield. Anal. Calcd for $\mathrm{C}_{44} \mathrm{H}_{35} \mathrm{~N}_{10} \mathrm{O}_{3.5}$ ((phen) $\left.)_{2}-\mathrm{TPA} \cdot 3 / 2 \mathrm{H}_{2} \mathrm{O}\right)$ : C, 69.50; H, 4.64; N, 18.43. Found: $\mathrm{C}$, 69.42; H, 4.65; N, 18.32. ${ }^{1} \mathrm{H}$ NMR $\left(\mathrm{CD}_{2} \mathrm{Cl}_{2}\right): \delta 3.69$ (s, 4H, CH2-py-6-Phen), 3.79 (s, 2H, CH2-py), 7.05 (t, $J=6 \mathrm{~Hz}, 1 \mathrm{H}$, py-H3), 7.22 (d, $J=7 \mathrm{~Hz}, 2 \mathrm{H}, \mathrm{H} 3$-py-6-phen), 7.47 (m, 8H, H4, H5 of py and H3, H6, H8 of phen), 7.67 (t, $J=7.2 \mathrm{~Hz}, 2 \mathrm{H}, \mathrm{H} 4$ of py-6-phen), 7.85 (d, $J=8.1 \mathrm{~Hz}, 2 \mathrm{H}, \mathrm{H} 5$ of phen), 7.99 (d, $J=8.1 \mathrm{~Hz}, 2 \mathrm{H}, \mathrm{H} 2$ of phen), $8.17(\mathrm{~d}, J=7.3 \mathrm{~Hz}, \mathrm{H} 5$ of py-6-phen), $8.36(\mathrm{~d}, J=4.0 \mathrm{~Hz}, 1 \mathrm{H}, \mathrm{H} 2$ of py), 8.68 (d, $J$ 
$=4.1 \mathrm{~Hz}, 2 \mathrm{H}, \mathrm{H} 6$ of Phen), $8.95(\mathrm{~d}, J=3.5 \mathrm{~Hz}, 2 \mathrm{H}, \mathrm{H} 9$ of phen), 9.90 (s, 2H, amide N-H) (Fig. S2). ESI-MS: $m / z=732.5\left([\mathrm{M}+\mathrm{H}]^{+}\right)$.

Synthesis of $\left.\left[\mathrm{Ru}^{I I} \mathrm{Cl}\left((\text { phen })_{2}-\mathrm{TPA}-\mathrm{H}^{+}\right) \mathrm{Ru}_{2}{ }_{2} \mathrm{Cl}_{2} \text { (p-cymene }\right)_{2}\right]\left(\mathrm{PF}_{6}\right)_{2}(2-\mathrm{Cl})$

A mixture of (phen) $)_{2}-\mathrm{TPA}(50 \mathrm{mg}, 0.068 \mathrm{mmol})$ and $\left[\mathrm{Ru}^{\mathrm{II}} \mathrm{Cl}_{2}(p-\text { cymene })\right]_{2}(63 \mathrm{mg}$, $0.102 \mathrm{mmol})$ was refluxed for $6 \mathrm{~h}$ in methanol $(10 \mathrm{ml})$. After filtration, $\mathrm{NH}_{4} \mathrm{PF}_{6}(55 \mathrm{mg}$, $0.34 \mathrm{mmol}$ ) was added to the filtrate and the solution was condensed under reduced pressure and then a brown powder emerged. After filtration, the residue on the filter paper was washed with dry ethanol and diethylether. The solid obtained was recrystallized from methanol (62 mg, 52\% yield). Anal. Calcd for $\mathrm{C}_{64} \mathrm{H}_{60.5} \mathrm{~N}_{10} \mathrm{O}_{2} \mathrm{Ru}_{3} \mathrm{P}_{2.5} \mathrm{~F}_{15}\left(1 / 2(\mathbf{2}-\mathbf{C l}) \cdot 1 / 2\left(\mathbf{2}-\mathbf{C l}+\mathrm{H}^{+} \cdot \mathrm{PF}_{6}\right)\right)$ : C, 43.34; H, 3.44; N, 7.89 . Found: $\mathrm{C}, 43.15 ; \mathrm{H}, 3.53 ; \mathrm{N}, 7.79 .{ }^{1} \mathrm{H}$ NMR $\left(\mathrm{CD}_{3} \mathrm{CN}\right): \delta 0.87,0.95,1.03,1.13(\mathrm{~d}, J=$ $\left.6.1 \mathrm{~Hz}, 12 \mathrm{H}, \mathrm{cym}^{i}{ }^{i} \mathrm{Pr}-\mathrm{CH}_{3}\right), 2.25,2.28\left(\mathrm{~s}, 6 \mathrm{H}, \mathrm{cym}-\mathrm{CH}_{3}\right), 2.70,2.72(\mathrm{~h}, J=6.6 \mathrm{~Hz}, 2 \mathrm{H}$, cym- $\left.{ }^{i} \mathrm{Pr}-\mathrm{CH}\right)$, 4.28, $4.66\left(\mathrm{ABq}, 4 \mathrm{H}\right.$, eq $\left.\mathrm{CH}_{2}\right), 5.02\left(\mathrm{ABq}, 2 \mathrm{H}\right.$, ax $\left.\mathrm{CH}_{2}\right), 5.45(\mathrm{t}, J=5.4$ $\mathrm{Hz}, 1 \mathrm{H}$, pyr-H4), 6.18 (m, 8H, cym-H2, 3, 5, 6) , 8.02 (t, J=5.6 Hz, 1H, phen' -H8), $8.14(\mathrm{t}, J=7.2 \mathrm{~Hz}, 1 \mathrm{H}$, phen'-H8 $), 6.81 （ \mathrm{~d}, J=4.0 \mathrm{~Hz}, 1 \mathrm{H}, \mathrm{pyr}-\mathrm{H} 6), 7.08 （ \mathrm{~d}, J=7.9$ Hz, 1H, pyr-H3), 7.20 (t, $J=6.4 \mathrm{~Hz}, 1 \mathrm{H}, \mathrm{pyr}-\mathrm{H} 4), 7.53$ (t, $\left.J=6.6 \mathrm{~Hz}, 1 \mathrm{H}, \mathrm{pyr}{ }^{\prime}{ }^{-}-\mathrm{H} 4\right)$,

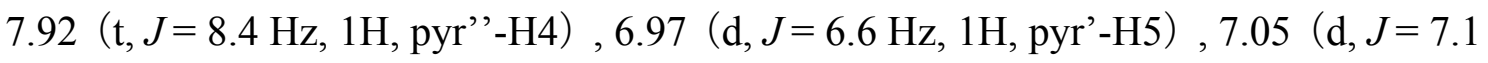
$\mathrm{Hz}, 1 \mathrm{H}$, pyr'-H3) $, 7.32\left(\mathrm{~d}, J=6.9 \mathrm{~Hz}, 1 \mathrm{H}, \mathrm{pyr}{ }^{\prime}-\mathrm{H} 5\right), 8.26(\mathrm{~d}, J=7.9 \mathrm{~Hz}, 1 \mathrm{H}$, pyr''-H3）, 8.47 (d, $J=8.5 \mathrm{~Hz}, 1 \mathrm{H}$, pyr'-H6）, 8.67 (d, $J=7.4 \mathrm{~Hz}, 1 \mathrm{H}$, phen'-H7）, $9.71(\mathrm{~d}, J=3.8 \mathrm{~Hz}, 1 \mathrm{H}$, phen'’-H9) , $9.78 （ \mathrm{~d}, J=3.6 \mathrm{~Hz}, 1 \mathrm{H}$, phen'-H7) , 10.07 (d, $J$ $=4.9 \mathrm{~Hz}, 1 \mathrm{H}$, phen'-H9) , 6.41-8.99 (m, 8H, phen-H) (Fig. S3). ESI-MS: $m / z=705.3$ $\left(\left[\mathrm{M}-2\left(\mathrm{PF}_{6}\right)\right]^{2+}\right)\left(\right.$ Fig. S4). $\lambda_{\max }(\mathrm{nm}), \varepsilon\left(\mathrm{M}^{-1} \mathrm{~cm}^{-1}\right)\left(\right.$ in $\left.\mathrm{CH}_{3} \mathrm{CN}\right): 410$ (br), $2.0 \times 10^{4} ; 270$, $1.26 \times 10^{5}$ (Fig. S5).

Synthesis of $\left[\mathrm{Ru}^{\mathrm{II}} \mathrm{Cl}\left((\mathrm{Phen})_{2}-\mathrm{TPA}-\mathrm{H}^{+}\right) \mathrm{Ru}^{\mathrm{II}}{ }_{2} \mathrm{Cl}_{2}(\mathrm{hmb})_{2}\right](\mathrm{PF})_{2}(\mathbf{1 - C l})$

This compound was prepared by a similar procedure with $\left[\mathrm{Ru}^{\mathrm{II}} \mathrm{Cl}_{2}(\mathrm{hmb})\right]_{2}(70 \mathrm{mg}$, $0.102 \mathrm{mmol}$ ) as described above except the reaction time: refluxing for $3 \mathrm{~h}$. (60 $\mathrm{mg}, 50 \%$ 
yield) Anal. Calcd for $\mathrm{C}_{68} \mathrm{H}_{68} \mathrm{~N}_{10} \mathrm{O}_{2} \mathrm{Cl}_{3} \mathrm{Ru}_{3} \mathrm{P}_{2} \mathrm{~F}_{12} \mathrm{C}, 46.49 ; \mathrm{H}, 3.90 ; \mathrm{N}, 7.79$. Found: $\mathrm{C}$, 46.27; $\mathrm{H}, 4.00 ; \mathrm{N}, 8.21 .{ }^{1} \mathrm{H}$ NMR $\left(\mathrm{CD}_{3} \mathrm{CN}\right): \delta$ 4.26-5.34 (ABq (broadening), $-\mathrm{CH}_{2}-$ ), 7.03-9.37 (multiplet, aromatics) $10.0\left(\mathrm{~s}\right.$, amide-NH). $\left(\lambda_{\max }(\mathrm{nm}),\left(\mathrm{M}^{-1} \mathrm{~cm}^{-1}\right)\right)$ in $\mathrm{CH}_{3} \mathrm{CN}$ : 432 (br), $1.5 \times 10^{4} ; 276,8.0 \times 10^{4}$ (Fig. S6). ESI-MS: $m / z=733.0\left(\left[\mathrm{M}-2\left(\mathrm{PF}_{6}\right)\right]^{2+}\right)($ Fig. S7b).

Synthesis of $\left[\mathrm{Ru}^{\mathrm{II}}\left(\mathrm{H}_{2} \mathrm{O}\right)\left((\mathrm{Phen})_{2}-\mathrm{TPA}-\mathrm{H}^{+}\right) \mathrm{Ru}_{2}{ }_{2}\left(\mathrm{H}_{2} \mathrm{O}\right)_{2}(\mathrm{hmb})_{2}\right]\left(\mathrm{PF}_{6}\right)_{5}\left(\mathrm{1}-\mathrm{H}_{2} \mathrm{O}\right)$

To the solution of 1-Cl $(50 \mathrm{mg}, 0.029 \mathrm{mmol})$ in water $(10 \mathrm{ml}), \mathrm{Ag}_{2} \mathrm{SO}_{4}(13.7 \mathrm{mg}$, $0.044 \mathrm{mmol}$ ) was added to reflux for 1 hour with aluminum foil for blind lights. The solution was filtrated to remove $\mathrm{AgCl}$, then solvent was evaporated to yield brown solid 1-H H $_{2}$. ${ }^{1} \mathrm{H}$ NMR $\left(\mathrm{CD}_{3} \mathrm{CN}\right): \delta$ 1.77, 1.90 (s, hmb-Me), 3.55-4.94 (ABq (broadening), $\left.-\mathrm{CH}_{2}-\right), 6.95-9.43$ (multiplet, aromatics). ESI-MS: $\mathrm{m} / \mathrm{z}=727.6\left(\left[\mathrm{M}-3 / 2\left(\mathrm{SO}_{4}\right)-3 \mathrm{H}_{2} \mathrm{O}\right]^{2+}\right)$ (Fig. S7a). Absorption spectrum: $\lambda_{\max }(\mathrm{nm}), \varepsilon\left(\mathrm{M}^{-1} \mathrm{~cm}^{-1}\right)\left(\right.$ in $\left.\mathrm{H}_{2} \mathrm{O}\right): 416$ (shoulder), $7.8 \times$ $10^{3} ; 280,2.9 \times 10^{4}$ (Fig. S8).

\section{Transfer Hydrogenation Reactions}

Substrates $(0.06 \mathrm{mmol})$ and HCOONa $(20.4 \mathrm{mg}, 0.3 \mathrm{mmol})$ were dissolved in $\mathrm{D}_{2} \mathrm{O} / \mathrm{CD}_{3} \mathrm{OD}(1: 1)(0.6 \mathrm{ml})$ under $\mathrm{N}_{2}$ atmosphere. The mixture was heated and kept at $50{ }^{\circ} \mathrm{C}$ during reaction time and then cooled to room temperature and the resulting mixture was analyzed by ${ }^{1} \mathrm{H}$ NMR measurements. Since each reaction for a carbonyl compound gave only one alcoholic product, we determined conversion of reaction as the ratio of peak integration value at the beginning and that at an appropriate reaction time. To determine the amount of the product, we used the amount of consumed substrate and calculated the turnover number by dividing that by the amount of catalyst used. We used the peaks at $2.34 \mathrm{ppm}$ for cyclohexanone, $9.94 \mathrm{ppm}$ for benzaldehyde (-CHO), $2.79 \mathrm{ppm}$ for acetophenone $\left(-\mathrm{CH}_{3}\right)$, and $7.57 \mathrm{ppm}(\mathrm{o}-\mathrm{H})$ for benzophenone for determination of the amount of substrates in the course of the reactions. 


\section{Kinetics of Hydrido Complexes}

1- $\mathrm{H}_{2} \mathrm{O}$ or $3-\mathrm{H}_{2} \mathrm{O}(0.2 \mathrm{mmol})$ was dissolved in $\mathrm{H}_{2} \mathrm{O}(2 \mathrm{ml})$ under Ar atmosphere. Aqueous HCOONa solution (2 M) was added to the $\mathbf{1 - \mathbf { H } _ { 2 }} \mathbf{O}$ or $\mathbf{3}-\mathbf{H}_{2} \mathbf{O}$ solution to be (10, 100,500 , and $1000 \mathrm{mM}$ ) and heated at $50{ }^{\circ} \mathrm{C}$ for requisited times. The mixture was monitored by UV-vis spectroscopic measurements at $500 \mathrm{~nm}$ for $\mathbf{1 - \mathbf { H } _ { 2 }} \mathbf{O}$ and $450 \mathrm{~nm}$ for 3-H2 $-\mathrm{H}_{2}$. The mixture was diluted with $\mathrm{MeOH}(\mathrm{mM})$ and analyzed by ESI-MS. To the mixture was added cyclohexanone $(0.02,0.2,1$, and $20 \mathrm{mmol})$ and was analyzed by $\mathrm{UV}$-vis spectrum measurements at $500 \mathrm{~nm}$ for $\mathbf{1}-\mathbf{H}_{2} \mathbf{O}$ and $450 \mathrm{~nm}$ for $\mathbf{3}-\mathbf{H}_{2} \mathbf{O}$.

\section{Acknowledgement}

This work was supported by Grants-in-Aid (Nos. 21750146, 21350035 and 20108010), a Global COE program, "the Global Education and Research Center for Bio-Environmental Chemistry" from the Japan Society of Promotion of Science (JSPS), and by KOSEF/MEST through WCU project (R31-2008-000-10010-0).

\section{Appendix A. Supplementary material}

Supplementary data associated with this article can be found, in the online version, at doi:Xxxxx.

\section{References}

[1] (a) R. Malacea, R. Poli, E. Manoury, Coord. Chem. Rev. 254 (2010) 729-752. (b) S. Gladiali, E. Alberico, Chem. Soc. Rev. 35 (2006) 226-236. (c) R.H. Morris, Chem. Soc. Rev. 38 (2009) 2282-2291.

[2] (a) L. A. Saudan, Acc. Chem. Res. 40 (2007) 1309-1319. (b) G. Zassinovich, G. Mestroni, S. Gladiali, Chem. Rev. 92 (1992) 1051-1069.

[3] (a) J. Wettergren, E. Buitrago, P. Ryberg, H. Adolfsson, H. Chem.-Eur. J. 15 
(2009) 5709-5718. (b) C.S. Yi, Z. He, I.A. Guzei, Organometallics 20 (2001) 3641-3643. (c) T. Kimura, H. Arita, S. Kuwata, T. Ikariya, Dalton Trans. (2009) 2912-2914. (d) T. Nishiguchi, K. Tanaka, K. Fukuzumi, J. Organomet. Chem. 193 (1980) 37-46. (e) T. Nishiguchi, K. Tachi, K. Fukuzumi, J. Am. Chem. Soc. 94 (1972) 8916-8917.

[4] Amines and imines have also been utilized as hydride sources. See: R. Andrés, M.V. Galakhov, M.P. Gómez-Sal, A. Martín, M. Mena, M.C. Morales-Varela, C. Santamaría, Chem.-Eur. J. 8 (2002) 805-811.

[5] (a) T. Hamada, T. Torii, T. Onishi, K. Izawa, T. Ikariya, J. Org. Chem. 69 (2004) 7391-7394. (b) N. Uematsu, A. Fujii, S. Hashiguchi, T. Ikariya, R. Noyori, J. Am. Chem. Soc. 118 (1996) 4916-4917.

[6] (a) C. Wang, C. Li, X. Wu, A. Pettman, J. Xiao, Angew. Chem. Int. Ed. 48 (2009) 6524-6528. (b) L. Yin, W. Shan, X. Jia, X. Li, A.S.C. Chan, J. Organomet. Chem. 694 (2009) 2092-2095. (c) Y. Himeda, N. Onozawa-Komatsuzaki, S. Miyazawa, H. Sugihara, T. Hirose, K. Kasuga, Chem.-Eur. J. 14 (2008) 11076-11081.

[7] (a) S. Fukuzumi, T. Kobayashi, T. Suenobu, J. Am. Chem. Soc. 132 (2010) 1496-1497. (b) S. Fukuzumi, T. Kobayashi, T. Suenobu, ChemSusChem 1 (2008) 827-834.

[8] S. Fukuzumi, T. Kobayashi, T. Suenobu, J. Am. Chem. Soc. 132 (2010) 11866-11867.

[9] (a) T. Zweifel, J.-V. Naubron, T. Büttner, T. Ott, H. Grützmacher, Angew. Chem. Int. Ed. 47 (2008) 3245-3249. (b) M. Poyatos, W. McNamara, C. Incarvino, E. Clot, E. Peris, R.H. Crabtree, Organometallics 27 (2008) 2128-2136.

[10] (a) S. Ogo, T. Abura, Y. Watanabe, Organometallics 21 (2002) 2964-2969. (b) C. Thoumazet, M. Melaimi, L. Ricard, F. Mathey, P. Le Floch, Organometallics 22 (2003) 1580-1581. (c) P. Braunstein, F. Naud, A. Pfaltz, S.J. Rettig, Organometallics 19 (2000) 2676-2683. (d) W. Baratta, G. Chelucci, S. Gladiali, K. 
Siega, M. Toniutti, M. Zanette, E. Zangrando, P. Rigo, Angew. Chem. Int. Ed. 44 (2005) 6214-6219.

[11] (a) S. Ogo, N. Makihara, Y. Watanabe, Organometallics 18 (1999) 5470-5474. (b) N. Tsoureas, G.R. Owen, A. Hamilton, A.G. Orpen, Dalton Trans. (2008) 6039-6044. (c) S.B. Han, I.S. Kim, M.J. Krische, Chem. Commun. (2009) $7278-7287$.

[12] (a) P. Vaestilae, A.B. Zaitsev, J. Wettergren, T. Privalov, H. Adolfsson, Chem.-Eur. J. 12 (2006) 3218-3225. (b) V. Cadierno, P. Crochet, J. Diez, J. Garcia-Alvarez, S.E. Garcia-Garrido, S. Garcia-Granda, J. Gimeno, M.A. Rodriguez, Dalton Trans. (2003) 3240-3249.

[13] (a) V. Cadierno, P. Crochet, J. Francos, S.E. Garcia-Garrido, J. Gimeno, N. Nebra, Green Chem. 11 (2009) 1992-2000. (b) P. Crochet, M.A. Fernandez-Zumel, C. Beauquis, J. Gimeno, Inorg. Chim. Acta 356 (2003) 114-120. (c) A. Ohki, T. Nishiguchi, K. Fukuzumi, J. Org. Chem. 44 (1979) 766-771.

[14] X. Wu, J. Liu, D. Di Tommaso, J.A. Iggo, C.R.A. Catlow, J. Basca, J. Xiao, Chem.-Eur. J. 14 (2008) 7699-7715.

[15] (a) T. Ikariya, A.J. Blacker, Acc. Chem. Res. 40 (2007) 1300-1308. (b) S. Hashiguchi, A. Fujii, J. Takehara, T. Ikariya, R. Noyori, J. Am. Chem. Soc. 117 (1995) $7562-7563$.

[16] (a) I. Guzman-Jimenez, J.W. van Hal, K.H. Whitmire, Organometallics 22 (2003) 1914-1922. (b) R. Paollilo, V. Gallo, G.F. Nobile, J. Rosé, P. Braunstein, Organometallics 27 (2008) 741-746.

[17] (a) B. Therrien, G. Süss-Fink, P. Govindaswamy, C. Saïd-Mohamed, Polyhedron 26 (2007) 4065-4072. (b) O. Hamelin, M. Rimboud, J. Pécaut, M. Fontecave, Inorg. Chem. 46 (2007) 5354-5360. (c) M. Aydemir, A. Baysal, N. Meric, B. Gümgüm, J. Organomet. Chem. 694 (2009) 2488-2492. (d) C. Ganesamoorthy, M.S. Balakrishna, J.T. Mague, J. Organomet. Chem. 694 (2009) 3390-3394. (e) A. 
Zanardi, J.A. Mata, E. Peris, J. Am. Chem. Soc. 131 (2009) 14531-14537.

[18] T. Kojima, N. Hirasa, D. Noguchi, T. Ishizaka, S. Miyazaki, Y. Shiota, K. Yoshizawa, S. Fukuzumi, Inorg. Chem. 49 (2010) 3737-3745.

[19] T. Kojima, K. Hayashi, Y. Matsuda, Inorg. Chem. 43 (2004) 6793-6804.

[20] K. Hara, H. Sugihara, L.P. Singh, A. Islam, R. Katoh, M. Yanagida, K. Sayama, H. Arakawa, J. Photochem. Photobiol. A 145 (2001) 117-122.

[21] (a) T. Kojima, K. Hayashi, Y. Matsuda, Chem. Lett. (2000) 1008-1009. (b) T. Kojima, S. Miyazaki, K. Hayashi, Y. Shimazaki, F. Tani, Y. Naruta, Y. Mastuda, Chem.-Eur. J. 10 (2004) 6402-6410. (c) T. Kojima, K. Hayashi, Y. Shiota, Y. Tachi, Y. Naruta, T. Suzuki, K. Uezu, K. Yoshizawa, Bull. Chem. Soc. Jpn. 78 (2005) 2152-2158. (d) T. Kojima, D. Noguchi, T. Nakayama, Y. Inagaki, Y. Shiota, K. Yoshizawa, K. Ohkubo, S. Fukuzumi, Inorg. Chem. 47 (2008) 886-895.

[22] K. Jitsukawa, Y. Oka, S. Yamaguchi, H. Masuda, Inorg. Chem. 43 (2004) 8119-8129.

[23] J. Canivet, L. Karmazin-Brelot, G. Süss-Fink, J. Organomet. Chem. 690 (2005) $3202-3211$.

[24] P. Štěpnička, J. Ludvík, J. Canivet, G. Süss-Fink, Inorg. Chim. Acta 359 (2006) 2369-2374.

[25] M. Yamakawa, H. Ito, R. Noyori, J. Am. Chem. Soc. 122 (2000) 1466-1478.

[26] $\left[\mathrm{Ru}^{\mathrm{II}} \mathrm{Cl}(\mathrm{phen})(\mathrm{hmb})\right] \mathrm{PF}_{6}$; Calcd for $\mathrm{C}_{24} \mathrm{H}_{26} \mathrm{~N}_{2} \mathrm{RuClPF}_{6}$ : C, 46.20; H, 4.20; N, 4.49. Found: C, 45.86; H, 4.11; N, 4.50. 